\title{
Synthesis and Cytotoxic Evaluation of $\mathrm{N}$-Alkyl-2-halophenazin-1- ones
}

\author{
Haruki Kohatsu, Shogo Kamo, Masateru Furuta, Shusuke Tomoshige, and Kouji Kuramochi* \\ Cite This: ACS Omega 2020, 5, 27667-27674 \\ Read Online
}

ABSTRACT: In this study, the synthesis of $N$-alkyl-2-halophenazin-1-ones has been established. Six $N$-alkyl-2-halophenazin-1-ones, including WS-9659 B and marinocyanins A and B, were synthesized by the direct oxidative condensation of 4-halo-1,2,3benzenetriol with the corresponding $N$-alkylbenzene-1,2-diamines. One of the most significant features of the present method is that it can be successfully applied to the synthesis of $N$-alkyl-2chlorophenazin-1-ones. The traditional chlorination of $\mathrm{N}$-alkylphenazin-1-ones with $\mathrm{N}$-chlorosuccinimide selectively occurs at the 4-position to afford the undesired $\mathrm{N}$-alkyl-4-chlorophenazin-1ones. Our synthetic route successfully circumvents this problem, culminating in the first chemical synthesis of WS-9659 B. The

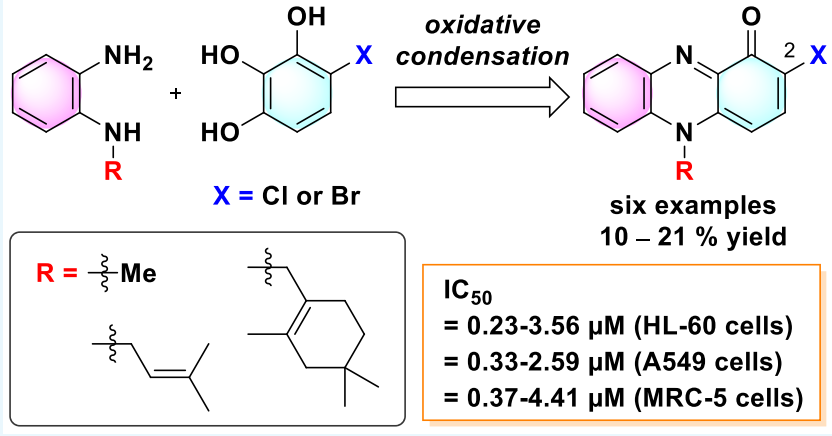
cytotoxicity of six $\mathrm{N}$-alkyl-2-halophenazin-1-ones and three $\mathrm{N}$ alkylphenazin-1-ones against human promyelocytic leukemia HL-60, human lung cancer A549, and normal MRC-5 cells was evaluated. Among the compounds tested in this study, 2-chloropyocyanin possesses significant selectivity toward A549 cells. The cytotoxic evaluation provides structural insights into the potency and selectivity of these compounds for cancer cells.

\section{INTRODUCTION}

Phenazines are a large group of nitrogen-containing heterocycles. To date, more than 100 phenazine derivatives have been identified in nature and over 6000 phenazine compounds synthesized. ${ }^{1-4} \mathrm{~N}$-Alkylphenazin-1-ones are a minor group of the phenazines. To the best of our knowledge, only four $\mathrm{N}$ alkylphenazin-1-ones [pyocyanin, ${ }^{5-10}$ lavanducyanin (WS9659 A), ${ }^{11-15}$ phenazinomycin, ${ }^{16,17}$ and 1-hydroxy-7-oxolavanducyanin $^{18}$ and seven $N$-alkyl-2-halophenazin-1-ones (WS$9659 \mathrm{~B}^{12-14}$ and marinocyanins $\mathrm{A}-\mathrm{F}^{15,19}$ ) have been identified as natural products. In the present study, we focused on $\mathrm{N}$ alkylphenazin-1-ones and $N$-alkyl-2-halophenazin-1-ones, which are depicted in Figure 1. Among them, pyocyanin (1a), lavanducyanin (WS-9659 A) (2a), WS-9659 B (2c), and marinocyanins A $(\mathbf{2 b})$ and B $(\mathbf{3 b})$ are natural products, which were isolated from Pseudomonas and Streptomyces species (Figure 1). ${ }^{3,4}$ One of the simplest and best-known $N$ alkylphenazin-1-ones is pyocyanin (1a) isolated from Pseudomonas aeruginosa., ${ }^{5,6}$ Pyocyanin shows several biological activities including antibacterial, antifungal, and cytotoxic activities. ${ }^{5}$ This compound plays an important role in biofilm formation and quorum sensing in $P$. aeruginosa. $^{6-10}$ Lavanducyanin (2a), isolated from the Streptomyces sp., shows cytotoxic activities against mouse leukemia P388 and mouse lymphoid leukemia L1210 cells with half-maximal inhibitory concentration $\left(\mathrm{IC}_{50}\right)$ values of 0.09 and $0.10 \mu \mathrm{g} / \mathrm{mL}$, respectively. ${ }^{11}$ The same compound and its 2-chlorinated derivative, respectively, named as WS-9659 A (2a) and WS-
9659 B (2c), were isolated from the Streptomyces sp. as testosterone $5 \alpha$-reductase inhibitors with $\mathrm{IC}_{50}$ values of 0.5 and $10 \mu \mathrm{M}$, respectively. ${ }^{12-14}$ Marinocyanins A (2b) and B (3b), 2-brominated derivatives, were isolated from a marine-derived Streptomyces sp. and actinomycete strains CNS-284 and CNY960. ${ }^{15,19}$ Compounds $\mathbf{2 b}$ and $\mathbf{3 b}$ inhibited TNF- $\alpha$-induced $\mathrm{NF} \kappa \mathrm{B}$ activity ( $\mathrm{IC}_{50}$ values of 4.1 and $24.2 \mu \mathrm{M}$, respectively) and LPS-induced nitric oxide production $\left(\mathrm{IC}_{50}\right.$ values of $>48.6$ and $15.1 \mu \mathrm{M}$, respectively). ${ }^{15}$ They blocked $\mathrm{PGE}_{2}$ production with greater efficacy $\left(\mathrm{IC}_{50}\right.$ values of 7.5 and $0.89 \mu \mathrm{M}$, respectively). ${ }^{15}$ Compounds $\mathbf{2 b}$ and $\mathbf{3 b}$ also showed strong cytotoxic activity against human colon carcinoma HCT116 cells with $\mathrm{IC}_{50}$ values of 0.049 and $0.029 \mu \mathrm{M}$, respectively. ${ }^{19} \mathrm{In}$ addition, both these compounds display modest antimicrobial activity against Staphylococcus aureus and the pathogenic yeast Candida albicans. ${ }^{19}$

Because of these diverse biological activities, $N$-alkylphenazin-1-ones are attractive synthetic targets. ${ }^{3,4,20-22}$ Our group recently reported the synthesis of $1 \mathbf{a}, \mathbf{2 a}, \mathbf{2 b}, \mathbf{3} \mathbf{a}$, and $3 \mathbf{b}$. $^{22}$ The oxidative condensation of pyrogallol with $N$-alkylbenzene-1,2-

Received: August 31, 2020

Accepted: October 2, 2020

Published: October 16, 2020 
<smiles>[X]c1ccc2n(C)c3ccccc3nc-2c1=O</smiles>

1a: $X=H$ (Pyocyanin) 1b: $X=\mathrm{Br}$ 1c: $X=\mathrm{Cl}$<smiles>[X]c1ccc2n(CC3=C(C)CC(C)(C)CC3)c3ccccc3nc-2c1=O</smiles>

2a: $X=H($ Lavanducyanin, WS-9659 A) 2b: $X=B r$ (Marinocyanin A) 2c: $X=C l(W S-9659 B)$<smiles>[X]c1ccc2n(CC=C(C)C)c3ccccc3nc-2c1=O</smiles>

3a: $X=\mathrm{H}$

3b: $X=B r$ (Marinocyanin B)

3c: $X=C l$

Figure 1. Structures of our target $N$-alkylphenazin-1-ones.

Scheme 1. Syntheses of Pyocyanin (1a), Lavanducyanin (2a), and Marinocyanins A (2b) and B (3b)
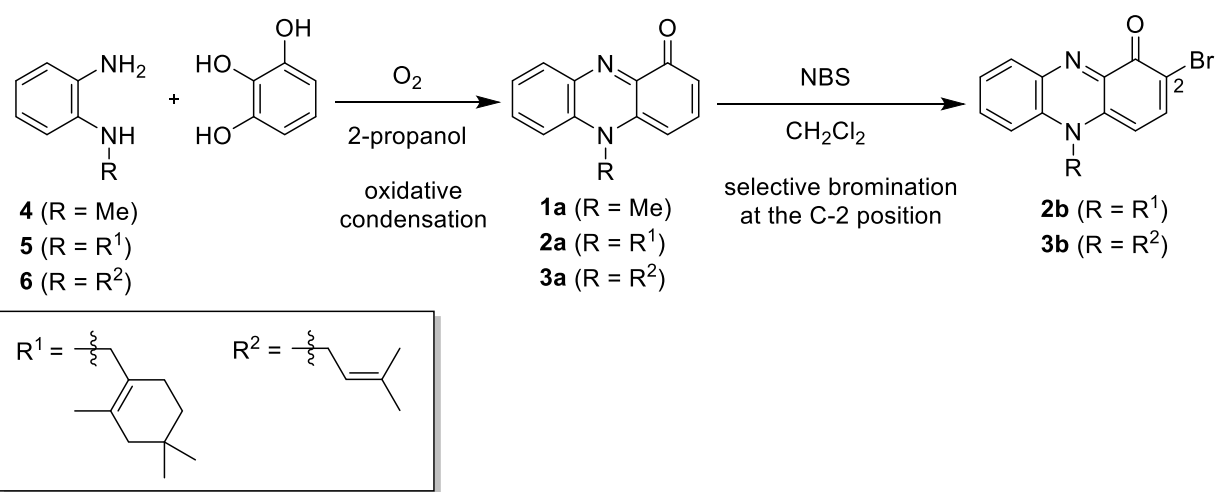

diamines (4, 5, and 6) under an oxygen atmosphere in 2propanol afforded $\mathbf{1 a}, \mathbf{2} \mathbf{a}$, and $\mathbf{3 a}$, respectively (Scheme 1). Bromination of the resultant phenazin-1-ones (2a and $3 a$ ) proceeded at the 2 -position in a regioselective manner to afford $\mathbf{2 b}$ and $\mathbf{3 b}$, respectively.

In the present study, we describe the synthesis of $\mathrm{N}$-alkyl-2halophenazin-1-ones by coupling 4-halo-1,2,3-benzenetriol with the corresponding $N$-alkylbenzene-1,2-diamines. The first synthesis of WS-9659 B (2c) was achieved by oxidative condensation of 4-chloro-1,2,3-benzenetriol with the corresponding $N$-alkylbenzene-1,2-diamine. Furthermore, the cytotoxic activities of synthetic $\mathrm{N}$-alkylphenazin-1-ones and $\mathrm{N}$ alkyl-2-halophenazin-1-ones were evaluated.

\section{RESULTS AND DISCUSSION}

Halogenation of Pyocyanin and Lavanducyanin. To obtain 2-chlorinated $\mathrm{N}$-alkylphenazin-1-ones, halogenation of pyocyanin (1a) was examined. A drastic change in the regioselectivity between bromination and chlorination was observed (Scheme 2). Bromination of 1a with $\mathrm{N}$-bromosuccinimide (NBS) in $\mathrm{CH}_{2} \mathrm{Cl}_{2}$ afforded 2-bromopyocyanin (1b) in $51 \%$ yield. However, chlorination of 1 a with $\mathrm{N}$-chlorosuccinimide (NCS) gave 4-chloropyocyanin (7) in 65\% yield. The position of the chlorine atom in 7 was confirmed by nuclear Overhauser effect spectroscopy (NOESY) correlations. NOESY correlations between $\mathrm{H}-2\left(\delta_{\mathrm{H}} 6.47\right)$ and $\mathrm{H}-3\left(\delta_{\mathrm{H}}\right.$ 7.44) and between the H-6 $\left(\delta_{\mathrm{H}} 7.40\right)$ and $N$-methyl group $\left(\delta_{\mathrm{H}}\right.$ 4.07) are observed (Figures 2, S32 and S33 in the Supporting Information). The difference in outcome can presumably be attributed to steric hindrance between the $N$-methyl group in 1a and the halogen atom. The van der Waals radius of a chlorine atom $(1.75 \AA)$ is smaller than that of a bromine atom $(1.85 \AA) .{ }^{23,24}$ Consequently, electrophilic substitution with the sterically large bromine atom at the 4-postion is disfavored.
Scheme 2. Selective Halogenation of Pyocyanin with NBS and NCS
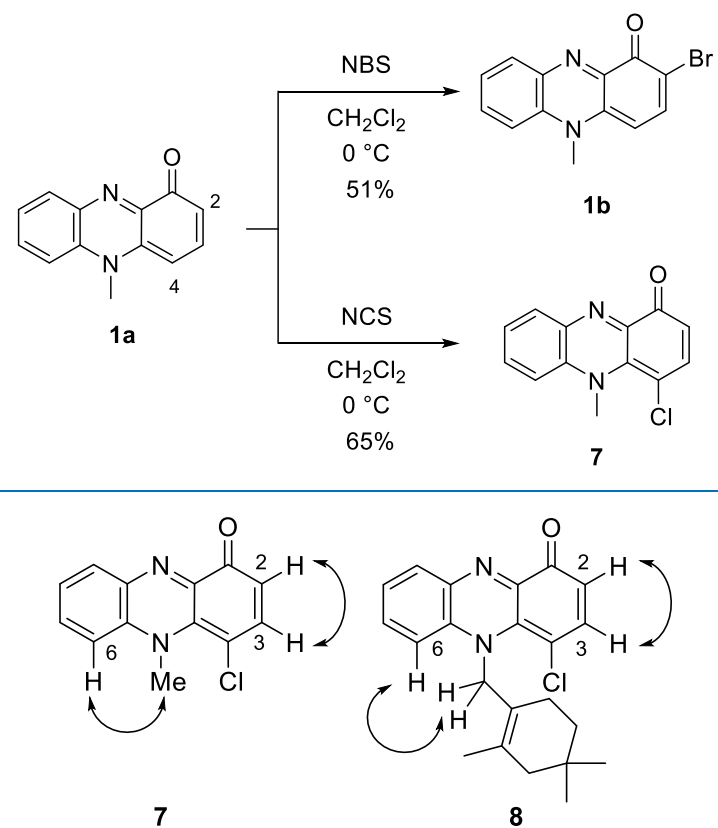

Figure 2. Selected NOESY correlations observed in 7 and $\mathbf{8}$.

The chlorination of lavanducyanin (2a) with NCS also proceeded at the 4-position in a regioselective manner to give 8 in $48 \%$ yield (Scheme 3 ). The position of the chlorine atom in $\mathbf{8}$ was also confirmed by NOESY correlations. NOESY correlations between $\mathrm{H}-2\left(\delta_{\mathrm{H}} 6.49\right)$ and $\mathrm{H}-3\left(\delta_{\mathrm{H}}\right.$ 7.46) and between the H-6 $\left(\delta_{\mathrm{H}} 7.27-7.25\right)$ and $N$-methylene group $\left(\delta_{\mathrm{H}}\right.$ 5.29) are observed (Figures 2 and S39 in the Supporting 
Scheme 3. Chlorination of Lavanducyanin (2a)

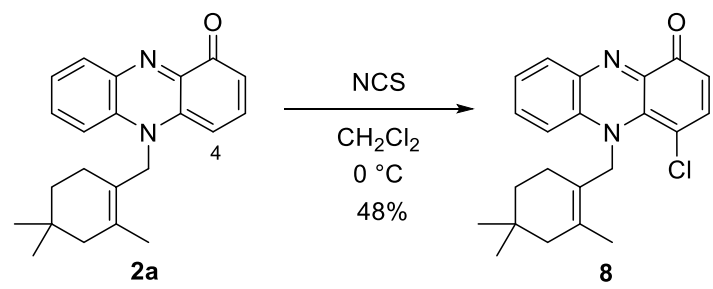

Information). Thus, an alternative methodology for the synthesis of WS-9659 B (2c) is needed.

Oxidative Condensation of 4-Halo-1,2,3-benzenetriol with $\mathrm{N}$-Alkylbenzene-1,2-diamines. To obtain $\mathrm{N}$-alkyl-2chlorophenazin-1-ones, reaction conditions for the oxidative condensation between the $N$-methylbenzene-1,2-diamine $(4)^{22}$ and 4-chloro-1,2,3-benzenetriol $(\mathbf{9})^{25}$ were examined (Table $1)$. When 4 and 9 were reacted under an oxygen atmosphere,

Table 1. Oxidative Condensation of 4-Chloro-1,2,3benzenetriol (9) with $N$-Methylbenzene-1,2-diamine $(4)^{a}$

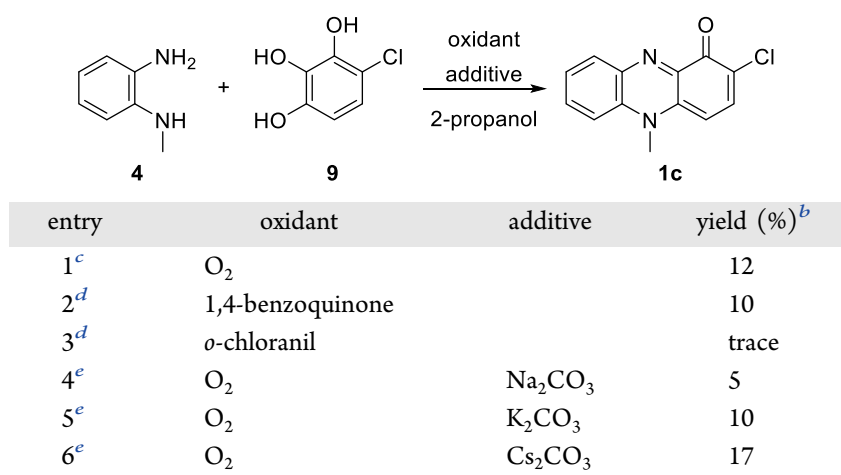

${ }^{a}$ Unless otherwise noted, reactions were performed using $4(0.246$ $\mathrm{mmol})$ and 9 (1.0 equiv) in 2-propanol $(2.0 \mathrm{~mL}) .{ }^{b}$ Isolated yield. ${ }^{c}$ The reaction was performed at room temperature $(\mathrm{rt})$ under an oxygen atmosphere. ${ }^{d}$ The reaction was performed at $0{ }^{\circ} \mathrm{C}$ under an argon atmosphere using the oxidant (3.0 equiv) indicated. ${ }^{e}$ The reaction was performed at $\mathrm{rt}$ under an oxygen atmosphere using the additive (1.0 equiv) indicated.

the desired 2-chloropyocyanin (1c) was obtained in $12 \%$ yield (entry 1). NOESY correlations between the $\mathrm{H}-4\left(\delta_{\mathrm{H}} 6.27\right)$ and $N$-methyl group $\left(\delta_{\mathrm{H}} 4.04\right)$ and between the H-6 $\left(\delta_{\mathrm{H}} 8.10\right)$ and $\mathrm{N}$-methyl group in 1c indicate the presence of the chlorine atom at the 2-position (Figures 3 and S11 in the Supporting

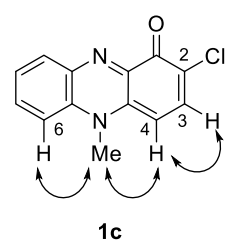

Figure 3. Selected NOESY correlations observed in 1c.

Information). The use of 1,4-benzoquinone as an oxidant gave $1 \mathrm{c}$ in $10 \%$ yield (entry 2 ). When $o$-chloranil was used in this reaction, only a trace amount of $1 \mathrm{c}$ was obtained. These results indicate that molecular oxygen is the optimal oxidant. The addition of bases to the oxidative coupling with molecular oxygen was also examined (entries 4-6). The yield of 1c was decreased by addition of $\mathrm{Na}_{2} \mathrm{CO}_{3}$ or $\mathrm{K}_{2} \mathrm{CO}_{3}$ (entries 4 and 5 , respectively) but slightly increased by addition of $\mathrm{Cs}_{2} \mathrm{CO}_{3}$ (entry 6). Other reaction conditions including the base, solvent, and temperature were also investigated but the yield of 1c was not improved. Thus, the entry 6 gave the optimal conditions.

Using optimal conditions, several $\mathrm{N}$-alkyl-2-halophenazin-1ones were prepared (Table 2). The first synthesis of WS-5659

Table 2. Oxidative Condensation of 4-Halo-1,2,3benzenetriols with $\mathrm{N}$-Alkylbenzene-1,2-diamine ${ }^{a}$

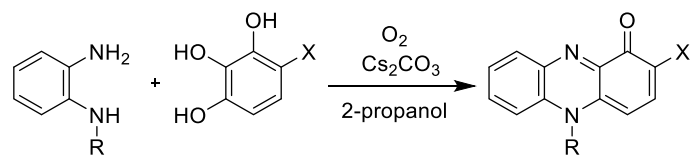

$$
\begin{array}{lr}
4(\mathrm{R}=\mathrm{Me}) & 9(\mathrm{X}=\mathrm{Cl}) \\
5\left(\mathrm{R}=\mathrm{R}^{1}\right) & 10(\mathrm{X}=\mathrm{Br})
\end{array}
$$$$
6\left(R=R^{2}\right)
$$

2c $\left(\mathrm{R}=\mathrm{R}^{1}, \mathrm{X}=\mathrm{Cl}\right)$ 3c $\left(R=R^{2}, X=C l\right)$ 1b $(R=M e, X=B r)$ 2b $\left(R=R^{1}, X=B r\right)$

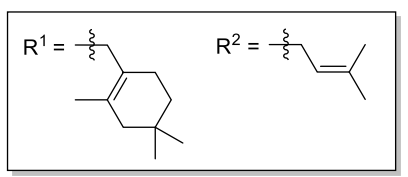
3b $\left(R=R^{2}, X=B r\right)$

$\begin{array}{ccccc}\text { entry } & \text { 1,2-diamine } & \text { 4-halo-1,2,3-benzenetriols } & \text { product } & \text { yield }(\%)^{b} \\ 1^{c} & \mathbf{5} & \mathbf{9} & \mathbf{2 c} & 20 \\ 2^{d} & \mathbf{6} & \mathbf{9} & 3 \mathbf{c} & 21 \\ 3^{d} & \mathbf{4} & \mathbf{1 0} & \mathbf{1 b} & 18 \\ 4^{c} & \mathbf{5} & \mathbf{1 0} & \mathbf{2 b} & 10 \\ 5^{d} & \mathbf{6} & \mathbf{1 0} & 3 \mathbf{b} & 15\end{array}$

${ }^{a}$ Unless otherwise noted, reactions were performed at $\mathrm{rt}$, with $\mathrm{O}_{2}$ bubbling or under an oxygen atmosphere, using $\mathrm{N}$-alkylbenzene-1,2diamine $(30.0 \mathrm{mg})$ and 4-halo-1,2,3-benzenetriols (1.0 equiv) in the presence of $\mathrm{Cs}_{2} \mathrm{CO}_{3}$ (1.0 equiv). ${ }^{b}$ Isolated yield. ${ }^{c}$ The reaction was performed with oxygen bubbling. ${ }^{d}$ The reaction was performed under an oxygen atmosphere.

B (2c) was achieved by coupling between 5 and 9 (entry 1). The ${ }^{1} \mathrm{H}$ and ${ }^{13} \mathrm{C}$ NMR spectroscopic data were identical to those reported for natural 2c. ${ }^{12}$ Oxidative coupling of 9 with 6 gave $3 \mathrm{c}$ in $21 \%$ yield (entry 2 ). The desired oxidative coupling also proceeded using 4-bromo-1,2,3-benzenetriol $(\mathbf{1 0})^{26}$ as a coupling partner to give $N$-alkyl-2-bromophenazin-1-ones. The coupling between $\mathbf{4}$ and $\mathbf{1 0}$ afforded 2-bromopyocyanin (1b) in $18 \%$ yield (entry 3 ). Marinocyanins A (2b) and B (3b) were synthesized by oxidative coupling of $\mathbf{1 0}$ with 5 and $\mathbf{6}$, respectively (entries 4 and 5 ).

Evaluation of Cytotoxic Activity against Human Cancer Cells and Normal Cells. Initially, the cytotoxic activity of $\mathbf{1 a}, \mathbf{1 b}$, and $\mathbf{1 c}$ against human promyelocytic leukemia HL-60 cells, human lung adenocarcinoma A549 cells, and human normal lung fibroblast MRC-5cells was evaluated using the WST-8 method. ${ }^{27}$ The concentrations of the compound required to reduce cell viability by $50 \%\left(\mathrm{IC}_{50}\right)$ are summarized in Table 3. Table 3 also shows the values of the selectivity index (SI), ${ }^{28-30}$ which is defined as the ratio of the $\mathrm{IC}_{50}$ value against normal cells to the corresponding $\mathrm{IC}_{50}$ value against cancer cells of similar tissue. Because both A549 and MRC-5 are derived from the lung, the SI value in Table 3 is defined as the $\mathrm{IC}_{50}$ value against normal MRC- 5 cells divided by the $\mathrm{IC}_{50}$ value against A549 cells. Generally, the compounds with a SI value higher than 2 are considered to give selective cytotoxicity against cancer cells. ${ }^{28} \mathrm{SN}-38$, the active metabolite of irinotecan, was used as a positive control. ${ }^{31}$ The cytotoxicity 
Table 3. Cytotoxic Activity of 1a-1c against Human Cancer Cells and Normal Cells $\left(\mathrm{IC}_{50}, \mu \mathrm{M}\right)$ and Their Selective Indexes $^{a}$

\begin{tabular}{llccc} 
& \multicolumn{3}{c}{$\mathrm{IC}_{50}(\mu \mathrm{M})$} \\
\cline { 2 - 4 } compounds & \multicolumn{1}{c}{ HL-60 } & A549 & MRC-5 & SI $^{c}$ \\
\cline { 2 - 4 } 1a & $5.82 \pm 0.133$ & $5.52 \pm 0.280$ & $21.8 \pm 2.550$ & 3.95 \\
1b & $3.07 \pm 0.080$ & $2.59 \pm 0.056$ & $3.36 \pm 0.204$ & 1.30 \\
1c & $3.56 \pm 0.052$ & $0.76 \pm 0.065$ & $4.41 \pm 0.069$ & 5.80 \\
SN-38 & $<0.05$ & $0.038 \pm 0.003$ & $<0.1$ &
\end{tabular}

${ }^{a}$ The concentration of the compound needed to reduce cell viability by $50 \%\left(\mathrm{IC}_{50}\right)$ was determined using the WST- 8 assay. $\mathrm{IC}_{50}$ values are expressed as the mean $\pm \mathrm{SD}$ of triplicate experiments. ${ }^{b} \mathrm{SN}-38$ was used as a positive control. ${ }^{c}$ The $\mathrm{SI}$ is defined as the $\mathrm{IC}_{50}$ value against normal MRC- 5 cells divided by the $\mathrm{IC}_{50}$ value against $\mathrm{A} 549$ cells.

against normal MRC-5 cells of 1a was less-potent than that against leukemia HL-60 cells and cancer A549 cells. The SI value of 1a $(\mathrm{SI}=3.95)$ indicates a significant selectivity toward cancer cells. However, the cytotoxicity of $\mathbf{1 b}$ against normal MRC- 5 cells was almost the same as that against leukemia HL60 cells and cancer A549 cells. Among compounds 1a-c, the compound 1c exhibited the most potent and selective cytotoxicity against cancer A549 cells. At least 5.8-fold and 4.6-fold higher concentrations of $1 \mathrm{c}$ are required to induce cytotoxicity against MRC-5 cells, as compared to those required against A549 and HL-60 cells, respectively. The differential cytotoxicity of $1 \mathrm{c}$ was highly significant $(\mathrm{SI}=5.80)$, suggesting that $\mathbf{1 c}$ is considered as a candidate for the development of chemotherapeutic agents. Pyocyanin (1a) has been reported to diffuse through the cell membrane and increase the intracellular ROS and $\mathrm{Ca}^{2+}$ levels. ${ }^{32}$ The presence of the chlorine atom at the 2-position in 1a may enhance the generation of ROSs or increase the chemical reactivity or binding affinity with the target molecules in A549 cells.

Next, the cytotoxic activity of $2 a-c$ and $3 a-c$ against HL60, A549, and MRC-5 cells was evaluated (Table 4). Although

Table 4. Cytotoxic Activity of 2 and 3 against Human Cancer Cells and Normal Cells $\left(\mathrm{IC}_{50}, \mu \mathrm{M}\right)$ and Their Selective Indexes ${ }^{a}$

\begin{tabular}{lrrrr} 
& \multicolumn{3}{c}{$\mathrm{IC}_{50}(\mu \mathrm{M})$} & \\
\cline { 2 - 4 } compounds & \multicolumn{1}{c}{ HL-60 } & \multicolumn{1}{c}{ A549 } & \multicolumn{1}{c}{ MRC-5 } & \multicolumn{1}{c}{ SI $^{c}$} \\
\cline { 2 - 4 } 2a & $0.36 \pm 0.023$ & $0.38 \pm 0.003$ & $0.68 \pm 0.013$ & 1.79 \\
2b & $0.27 \pm 0.017$ & $0.73 \pm 0.015$ & $0.60 \pm 0.008$ & 0.82 \\
2c & $0.23 \pm 0.013$ & $0.75 \pm 0.006$ & $0.37 \pm 0.019$ & 0.49 \\
3a & $2.59 \pm 0.195$ & $0.88 \pm 0.023$ & $0.87 \pm 0.063$ & 0.99 \\
3b & $0.67 \pm 0.038$ & $0.33 \pm 0.010$ & $0.54 \pm 0.009$ & 1.64 \\
3c & $2.20 \pm 0.070$ & $0.66 \pm 0.016$ & $0.66 \pm 0.041$ & 1.00 \\
SN-38 & $0.056 \pm 0.002$ & $0.052 \pm 0.003$ & $0.092 \pm 0.001$ & 1.77
\end{tabular}

${ }^{a}$ The concentration of the compound needed to reduce cell viability by $50 \%\left(\mathrm{IC}_{50}\right)$ was determined using the WST- 8 assay. $\mathrm{IC}_{50}$ values are expressed as the mean $\pm \mathrm{SD}$ of triplicate experiments. ${ }^{b} \mathrm{SN}-38$ was used as a positive control. ${ }^{c}$ The $\mathrm{SI}$ is defined as the $\mathrm{IC}_{50}$ value against normal MRC- 5 cells divided by the $\mathrm{IC}_{50}$ value against $\mathrm{A} 549$ cells.

these compounds showed cytotoxicity against HL-60 cells, compounds $3 a$ and $3 c$ displayed weaker activity than the other compounds. Compounds $2 \mathrm{a}-\mathrm{c}$ and $3 \mathrm{a}-\mathrm{c}$ exhibited cytotoxicity against A549 and MRC-5 cells at concentrations lower than $1 \mu \mathrm{M}$. Unfortunately, no significant difference in the $\mathrm{IC}_{50}$ values between these compounds was observed. The SI values of $2 a-c$ and $3 a-c$ are lower than 2. Selectivity against A549 cells was not observed. The displacement of the methyl group with the longer alkyl groups at the nitrogen atom in $\mathbf{1 a}$ and $\mathbf{1 c}$ decreased the selective cytotoxicity toward A549 cells.

\section{CONCLUSIONS}

In this study, the synthesis of $\mathrm{N}$-alkyl-2-halophenazin-1-one was established. Six $\mathrm{N}$-alkyl-2-halophenazin-1-ones, including WS-9659 B (2c) and marinocyanins A (2b) and B (3b), were synthesized by the oxidative condensation of 4-halo-1,2,3benzenetriols with $N$-alkylbenzene-1,2-diamines. The present strategy enables the highly convergent and selective synthesis of $\mathrm{N}$-alkyl-2-halophenazin-1-ones. In addition, the cytotoxicity of compounds $1 \mathbf{a}-\mathbf{c}, \mathbf{2 a}-\mathbf{c}$, and $3 \mathbf{a}-\mathbf{c}$ against human leukemia HL-60 cells, cancer A549 cells, and normal MRC-5 cells was evaluated. Among the compounds tested in this study, 2chloropyocyanin (1c) exhibited the most selective cytotoxicity against A549 cells. The high SI value of 1c $(\mathrm{SI}=5.80)$ suggests that $1 \mathrm{c}$ is considered as a potential candidate for the development of chemotherapeutic agents. Halogenated phenazines have recently attracted increasing attention as a promising class of biofilm-eradicating agents that effectively target multiple persistent bacterial phenotypes. ${ }^{33,34}$ Thus, halogenation of phenazines and phenazinones is one of the valuable approaches for improving their biological activities. ${ }^{35}$ The present study will be invaluable not only for analyzing the molecular and cellular biological activities of $\mathrm{N}$-alkylphenazin1 -ones and their halogenated derivatives but also in the design of more potent and selective cytotoxic derivatives against cancer cells. Additional biological studies to investigate the mechanism of action of these compounds are currently underway.

\section{EXPERIMENTAL SECTION}

General Information. All reactions sensitive to air or moisture were carried out under an argon atmosphere under anhydrous conditions, unless otherwise noted. Solvents and reagents were used without further purification unless otherwise noted. Analytical thin-layer chromatography (TLC) was performed using silica gel $60 \mathrm{~F}_{254}$ plates $(0.25$ $\mathrm{mm}$, normal phase, Merck) and silica gel $60 \mathrm{RP}-18 \mathrm{~F}_{254 \mathrm{~S}}$ plates $(0.25 \mathrm{~mm}$, reversed phase, Merck). Normal-phase flash column chromatography was performed using silica gel 60 (particle size 40-63 $\mu \mathrm{m}$; 230-400 mesh ASTM; SilicaFlash F60, SiliCycle Inc.). Reversed-phase flash column chromatography was performed using octadecylsilyl silica gel (C18, particle size 15-30 $\mu \mathrm{m}$, FUJIFILM Wako Pure Chemical Co.). Melting point $\left(M_{\mathrm{p}}\right)$ data were determined using a Shimadzu MM-2 instrument and were uncorrected. IR spectra were recorded on a Horiba FT-720 spectrometer, using $\mathrm{KBr}$ pellets (solid). ${ }^{1} \mathrm{H}$ and proton-decoupled ${ }^{13} \mathrm{C}\left({ }^{13} \mathrm{C}\{1 \mathrm{H}\}\right)$ NMR spectra were recorded on a Bruker Avance 400 spectrometer (400 and 100 $\mathrm{MHz}$, respectively), using chloroform-d $\left(\mathrm{CDCl}_{3}\right)$, dimethyl sulfoxide- $d_{6}\left(\mathrm{DMSO}-d_{6}\right)$, and methanol- $d_{4}\left(\mathrm{CD}_{3} \mathrm{OD}\right)$ as the solvent. Chemical shift values are expressed in $\delta(\mathrm{ppm})$ relative to tetramethylsilane (TMS, $\delta 0.00 \mathrm{ppm}$ ) or the residual solvent resonance $\left(\mathrm{CDCl}_{3}, \delta 77.0 \mathrm{ppm}\right.$ for ${ }^{13} \mathrm{C}$ NMR; DMSO- $d_{6}, \delta$ $2.49 \mathrm{ppm}$ for ${ }^{1} \mathrm{H}$ NMR and $\delta 39.7 \mathrm{ppm}$ for ${ }^{13} \mathrm{C} \mathrm{NMR}$; and $\mathrm{CD}_{3} \mathrm{OD}, \delta 3.30 \mathrm{ppm}$ for ${ }^{1} \mathrm{H} \mathrm{NMR}$ and $\delta 49.0 \mathrm{ppm}$ for ${ }^{13} \mathrm{C}$ NMR). Data are reported as follows: chemical shift, multiplicity $(\mathrm{s}=$ singlet, $\mathrm{d}=$ doublet, $\mathrm{t}=$ triplet, $\mathrm{q}=$ quartet, $\mathrm{br}=$ broad, and $\mathrm{m}=$ multiplet $)$, coupling constants $(J ; \mathrm{Hz})$, and 
integration. Mass spectra were obtained using a Sciex X500R quadrupole time-of-flight (QTOF) high-resolution mass spectrometer using electrospray ionization (ESI). High purity levels of all synthetic compounds were verified using ${ }^{1} \mathrm{H}$ NMR spectra (see the Supporting Information). A549 cells were purchased from the Riken Cell Bank. HL-60 and MRC-5 cells were purchased from the National Institute of Biomedical Innovation, Health and Nutrition.

2-Bromo-5-methylphenazin-1(5H)-one (1b). NBS (9.3 mg, $52.3 \mu \mathrm{mol})$ was added to a solution of $1 \mathrm{a}^{22}(10.6 \mathrm{mg}, 50.4$ $\mu \mathrm{mol})$ in $\mathrm{CH}_{2} \mathrm{Cl}_{2}(5.0 \mathrm{~mL})$. The mixture was stirred at $0{ }^{\circ} \mathrm{C}$ for $1 \mathrm{~h}$. The reaction was quenched by the addition of a saturated aqueous $\mathrm{NaHCO}_{3}$ solution. The mixture was diluted with $\mathrm{CHCl}_{3}$. After the layers were separated, the organic layer was washed with water and brine, dried over $\mathrm{Na}_{2} \mathrm{SO}_{4}$, and concentrated to give a residue. The residue was purified by reversed-phase flash chromatography $\left(\mathrm{MeOH} / \mathrm{H}_{2} \mathrm{O}=4 / 1\right)$ to give $\mathbf{1 b}(7.5 \mathrm{mg}, 51 \%)$ as a dark-blue solid. Reversed-phase TLC $\left(\mathrm{MeOH} / \mathrm{H}_{2} \mathrm{O}=4 / 1\right)$ Rf 0.48; mp $129-130{ }^{\circ} \mathrm{C}$; IR $(\mathrm{KBr}) \nu_{\max }: 2958,2914,2848,1724,1620,1560,1493 \mathrm{~cm}^{-1}$; ${ }^{1} \mathrm{H}$ NMR (400 MHz, DMSO- $\left.d_{6}\right): \delta 8.24(\mathrm{~d}, J=8.1 \mathrm{~Hz}, 1 \mathrm{H})$, 8.13-8.10 (m, 2H), $8.00(\mathrm{t}, J=7.6 \mathrm{~Hz}, 1 \mathrm{H}), 7.67(\mathrm{t}, J=7.6$ $\mathrm{Hz}, 1 \mathrm{H}), 6.25(\mathrm{~d}, J=8.6 \mathrm{~Hz}, 1 \mathrm{H}), 4.04(\mathrm{~s}, 3 \mathrm{H}) ;{ }^{13} \mathrm{C}\left\{{ }^{1} \mathrm{H}\right\}$ NMR (100 MHz, DMSO- $\left.d_{6}\right): \delta 171.0,145.4,144.5,136.4$, 136.0, 135.2, 133.0, 132.7, 125.8, 116.0, 108.3, 91.9, 35.7; HRMS (ESI/QTOF) $m / z:[\mathrm{M}+\mathrm{H}]^{+}$calcd for $\mathrm{C}_{13} \mathrm{H}_{10}{ }^{79} \mathrm{BrN}_{2} \mathrm{O}$, 288.9971; found, 288.9969.

4-Chloro-5-methylphenazin-1(5H)-one (7). NCS (7.1 mg, $53.2 \mu \mathrm{mol})$ was added to a solution of $1 \mathrm{a}^{22}(10.6 \mathrm{mg}, 50.4$ $\mu \mathrm{mol})$ in $\mathrm{CH}_{2} \mathrm{Cl}_{2}(5.0 \mathrm{~mL})$. The mixture was stirred at $0{ }^{\circ} \mathrm{C}$ for $2 \mathrm{~h}$. The reaction was quenched by the addition of a saturated aqueous $\mathrm{NaHCO}_{3}$ solution. The mixture was diluted with $\mathrm{CHCl}_{3}$. After the layers were separated, the organic layer was washed with water and brine, dried over $\mathrm{Na}_{2} \mathrm{SO}_{4}$, and concentrated to give a residue. The residue was purified by reversed-phase flash chromatography $\left(\mathrm{MeOH} / \mathrm{H}_{2} \mathrm{O}=4 / 1\right)$ to give $7(8.0 \mathrm{mg}, 65 \%)$ as a dark-blue solid. TLC $\left(\mathrm{CHCl}_{3} /\right.$ $\mathrm{MeOH}=9 / 1) \mathrm{Rf} 0.66 ; \mathrm{mp} 125-127^{\circ} \mathrm{C}$; IR (KBr) $\nu_{\text {max }}: 3035$, 2920, 1728, 1637, 1574, 1514, $1493 \mathrm{~cm}^{-1}$; ${ }^{1} \mathrm{H}$ NMR (400 $\mathrm{MHz}, \mathrm{CDCl}_{3}$, TMS $): \delta 8.17(\mathrm{dd}, J=8.1,1.1 \mathrm{~Hz}, 1 \mathrm{H}), 7.74-$ $7.70(\mathrm{~m}, 1 \mathrm{H}), 7.44(\mathrm{~d}, J=10.0 \mathrm{~Hz}, 1 \mathrm{H}), 7.44-7.40(\mathrm{~m}, 1 \mathrm{H})$, $7.40(\mathrm{~d}, J=8.6 \mathrm{~Hz}, 1 \mathrm{H}), 6.47(\mathrm{~d}, J=10.0 \mathrm{~Hz}, 1 \mathrm{H}), 4.07(\mathrm{~s}$, $3 \mathrm{H}) ;{ }^{13} \mathrm{C}\left\{{ }^{1} \mathrm{H}\right\}$ NMR $\left(100 \mathrm{MHz}, \mathrm{CDCl}_{3}\right): \delta$ 178.7, 146.9, 145.9, 136.0, 135.5, 134.6, 132.8, 132.7, 124.6, 119.1, 113.6, 100.3, 41.3; HRMS (ESI/QTOF) $m / z:[\mathrm{M}+\mathrm{H}]^{+}$calcd for $\mathrm{C}_{13} \mathrm{H}_{10}{ }^{35} \mathrm{ClN}_{2} \mathrm{O}$, 245.0476; found, 245.0478.

4-Chloro-5-\{(2,4,4-trimethylcyclohex-1-en-1-yl)methyl\}phenazin-1(5H)-one (8). NCS (4.5 mg, $33.7 \mu \mathrm{mol})$ was added to a solution of $2 \mathrm{a}^{22}(10.6 \mathrm{mg}, 31.9 \mu \mathrm{mol})$ in $\mathrm{CH}_{2} \mathrm{Cl}_{2}(3.0$ $\mathrm{mL})$. The mixture was stirred at $0{ }^{\circ} \mathrm{C}$ for $1.5 \mathrm{~h}$. The reaction was quenched by the addition of a saturated aqueous $\mathrm{NaHCO}_{3}$ solution. The mixture was diluted with $\mathrm{CHCl}_{3}$. After the layers were separated, the organic layer was washed with water and brine, dried over $\mathrm{Na}_{2} \mathrm{SO}_{4}$, and concentrated to give a residue. The residue was purified by reversed-phase flash chromatography $\left(\mathrm{MeOH} / \mathrm{H}_{2} \mathrm{O}=4 / 1\right)$ to give $8(5.6 \mathrm{mg}, 48 \%)$ as a darkblue solid. TLC $\left(\mathrm{CHCl}_{3} / \mathrm{MeOH}=9 / 1\right)$ Rf 0.47; mp 114-116 ${ }^{\circ} \mathrm{C}$; IR (KBr) $\nu_{\max }: 2954,2920,2850,1724,1716,1643,1603$, 1514, $1469 \mathrm{~cm}^{-1} ;{ }^{1} \mathrm{H}$ NMR (400 MHz, $\mathrm{CDCl}_{3}$ ): $\delta 8.18$ (dd, $J$ $=8.0,1.4 \mathrm{~Hz}, 1 \mathrm{H}), 7.65-7.61(\mathrm{~m}, 1 \mathrm{H}), 7.46(\mathrm{~d}, J=10.1 \mathrm{~Hz}$, $1 \mathrm{H}), 7.40(\mathrm{t}, J=8.0 \mathrm{~Hz}, 1 \mathrm{H}), 7.27-7.25^{*}(\mathrm{~m}, 1 \mathrm{H}), 6.49$ (d, $J$ $=10.1 \mathrm{~Hz}, 1 \mathrm{H}), 5.29(\mathrm{~s}, 2 \mathrm{H}), 1.81$ (br s, $5 \mathrm{H}), 1.48(\mathrm{br} \mathrm{s}, 2 \mathrm{H})$, $1.16(\mathrm{t}, J=6.4 \mathrm{~Hz}, 2 \mathrm{H}), 0.73(\mathrm{~s}, 6 \mathrm{H})$, (*this proton signal was assigned based on the HMQC spectrum.); ${ }^{13} \mathrm{C}\left\{{ }^{1} \mathrm{H}\right\} \mathrm{NMR}$ $\left(100 \mathrm{MHz}_{\mathrm{CDCl}}\right): \delta 178.8,146.9,146.4,136.1,134.7,134.0$, 133.0 (2C), 130.3, 124.6, 123.2, 118.9, 114.5, 100.4, 54.2, 46.2, 35.0, 28.9, 27.9 (2C), 23.2, 19.3; HRMS (ESI/QTOF) $m / z$ : $[\mathrm{M}+\mathrm{H}]^{+}$calcd for $\mathrm{C}_{22} \mathrm{H}_{24}{ }^{35} \mathrm{ClN}_{2} \mathrm{O}, 367.1572$; found, 367.1579 .

General Procedure for the Coupling between 4 and 9 under an Oxygen Atmosphere (Entries 1, 4, 5, and 6 in Table 1). A solution of $4(30.0 \mathrm{mg}, 245.6 \mu \mathrm{mol})$ and $9(1.0$ equiv) in the absence or presence of the additive (1.0 equiv) indicated in Table 1 in 2-propanol $(2.0 \mathrm{~mL})$ was stirred under an $\mathrm{O}_{2}$ atmosphere at $\mathrm{rt}$ in the dark until no further TLC changes were observed. The reaction was quenched by the addition of $1 \mathrm{M}$ aqueous $\mathrm{HCl}$ solution. The mixture was diluted with $\mathrm{CHCl}_{3}$. After the layers were separated, the aqueous layer was neutralized with $4 \mathrm{M}$ aqueous $\mathrm{NaOH}$ solution. The aqueous layer was extracted with $\mathrm{CHCl}_{3}$ twice. The combined organic layer was dried over $\mathrm{Na}_{2} \mathrm{SO}_{4}$ and concentrated to give a residue. The residue was purified by silica gel column chromatography and reversed-phase flash chromatography.

Following the general procedure, the reaction was performed using $4(30.0 \mathrm{mg}, 245.6 \mu \mathrm{mol})$ and $9(39.8 \mathrm{mg}, 247.9 \mu \mathrm{mol})$ in the presence of $\mathrm{Cs}_{2} \mathrm{CO}_{3}(81.0 \mathrm{mg}, 248.6 \mu \mathrm{mol})$ for 4 days to give $1 \mathrm{c}(10.3 \mathrm{mg}, 17 \%)$ as a dark-blue solid (entry 6). Reversed-phase TLC $\left(\mathrm{MeOH} / \mathrm{H}_{2} \mathrm{O}=4 / 1\right)$ Rf 0.39; mp 124$125^{\circ} \mathrm{C}$; IR $(\mathrm{KBr}) \nu_{\max }: 3043,2924,1716,1622,1560 \mathrm{~cm}^{-1} ; \mathrm{H}$ NMR (400 MHz, DMSO- $\left.d_{6}\right): \delta 8.24(\mathrm{dd}, J=8.2,1.2 \mathrm{~Hz}, 1 \mathrm{H})$, $8.10(\mathrm{~d}, J=8.7 \mathrm{~Hz}, 1 \mathrm{H}), 8.02-7.98(\mathrm{~m}, 1 \mathrm{H}), 7.96(\mathrm{~d}, J=8.7$ $\mathrm{Hz}, 1 \mathrm{H}), 7.66(\mathrm{td}, J=8.2,1.2 \mathrm{~Hz}, 1 \mathrm{H}), 6.27(\mathrm{~d}, J=8.7 \mathrm{~Hz}$, $1 \mathrm{H}), 4.04(\mathrm{~s}, 3 \mathrm{H}) ;{ }^{13} \mathrm{C}\{1 \mathrm{H}\} \mathrm{NMR}\left(100 \mathrm{MHz}, \mathrm{DMSO}-d_{6}\right): \delta$ $170.8,145.9,141.2$, 136.2, 136.0, 134.6, 133.0, 132.7, 125.8, 118.0, 115.9, 90.7, 35.6; HRMS (ESI/QTOF) $m / z:[\mathrm{M}+\mathrm{H}]^{+}$ calcd for $\mathrm{C}_{13} \mathrm{H}_{10}{ }^{35} \mathrm{ClN}_{2} \mathrm{O}$, 245.0476; found, 245.0476.

General Procedure for the Coupling between 4 and 9 Using the Oxidant (Entries 2 and 3 in Table 1). A solution of $4(245.6 \mu \mathrm{mol})$ and 9 (1.0 equiv) in the presence of the oxidant (3.0 equiv) indicated in Table 1 in 2-propanol (2.0 $\mathrm{mL}$ ) was stirred at $0{ }^{\circ} \mathrm{C}$ until no further TLC changes were observed. The reaction was quenched by the addition of $1 \mathrm{M}$ aqueous $\mathrm{HCl}$ solution. The mixture was diluted with $\mathrm{CHCl}_{3}$. After the layers were separated, the aqueous layer was neutralized with $4 \mathrm{M}$ aqueous $\mathrm{NaOH}$ solution. The aqueous layer was extracted with $\mathrm{CHCl}_{3}$ twice. The combined organic layer was dried over $\mathrm{Na}_{2} \mathrm{SO}_{4}$ and concentrated to give a residue. The residue was purified by silica gel column chromatography and reversed-phase flash chromatography to yield 1c.

Following the general procedure, the reaction was performed using 4 (30.0 mg, $245.6 \mu \mathrm{mol}), 9(40.0 \mathrm{mg}, 249.1 \mu \mathrm{mol})$, and 1,4-benzoquinone $(79.6 \mathrm{mg}, 736.4 \mu \mathrm{mol})$ for $1 \mathrm{~h}$ to give $1 \mathrm{c}$ (6.1 mg, 10\%) (entry 2).

General Procedure of $\mathrm{N}-\{(2,4,4-T$ rimethylcyclohex-1en-1-yl)methyl\}benzene-1,2-diamine (5) with 4-Halo1,2,3-benzenetriols (General Procedure A; Entries 1, 4 in Table 2). A solution of $N$-alkylbenzene-1,2-diamine (30.0 $\mathrm{mg}$ ) and 4-halo-1,2,3-benzenetriols (1.0 equiv) in the presence of the $\mathrm{Cs}_{2} \mathrm{CO}_{3}$ (1.0 equiv) in 2-propanol $(1.0 \mathrm{~mL})$ was stirred and bubbled with $\mathrm{O}_{2}$ from an $\mathrm{O}_{2}$ balloon at $\mathrm{rt}$ in the dark until no further TLC changes were observed. The reaction was quenched by the addition of water. The mixture was diluted with $\mathrm{CHCl}_{3}$. After the layers were separated, the organic layer was washed with water and brine, dried over $\mathrm{Na}_{2} \mathrm{SO}_{4}$, and 
concentrated to give a residue. The residue was purified by silica gel column chromatography and reversed-phase flash chromatography.

Marinocyanin A (2b). Following the general procedure A, the reaction was performed using $5(30.0 \mathrm{mg}, 122.8 \mu \mathrm{mol})$ and $10(25.2 \mathrm{mg}, 122.9 \mu \mathrm{mol})$ in the presence of $\mathrm{Cs}_{2} \mathrm{CO}_{3}(40.0$ $\mathrm{mg}, 122.8 \mu \mathrm{mol}$ ) in 2-propanol with $\mathrm{O}_{2}$ bubbling for 2 days. The residue was purified by silica gel column chromatography $\left(\mathrm{CHCl}_{3} / \mathrm{MeOH}=50 / 1\right)$ and reversed-phase flash chromatography $\left(\mathrm{MeOH} / \mathrm{H}_{2} \mathrm{O}=4 / 1\right)$ to give $2 \mathrm{~b}(5.0 \mathrm{mg}, 10 \%)$ as a dark-blue solid. The structure of $\mathbf{2 b}$ was confirmed by comparison of the ${ }^{1} \mathrm{H}$ and ${ }^{13} \mathrm{C}\left\{{ }^{1} \mathrm{H}\right\}$ NMR spectra with those reported for $\mathbf{2} \mathbf{b}^{22}$

WS-9659 B (2c). Following the general procedure A, the reaction was performed using $5(30.0 \mathrm{mg}, 122.8 \mu \mathrm{mol})$ and 9 $(19.9 \mathrm{mg}, 123.9 \mu \mathrm{mol})$ in the presence of $\mathrm{Cs}_{2} \mathrm{CO}_{3}(40.2 \mathrm{mg}$, $123.4 \mu \mathrm{mol}$ ) in 2-propanol with $\mathrm{O}_{2}$ bubbling for 2 days. The residue was purified by silica gel column chromatography $\left(\mathrm{CHCl}_{3} / \mathrm{MeOH}=50 / 1\right)$ and reversed-phase flash chromatography $\left(\mathrm{MeOH} / \mathrm{H}_{2} \mathrm{O}=4 / 1\right)$ to give $2 \mathrm{c}(8.9 \mathrm{mg}, 20 \%)$ as a dark-blue solid. Reversed-phase TLC $\left(\mathrm{MeOH} / \mathrm{H}_{2} \mathrm{O}=4 / 1\right) \mathrm{Rf}$ 0.43; mp $154-157{ }^{\circ} \mathrm{C}$ (lit. $\left.152-153{ }^{\circ} \mathrm{C}\right){ }^{12} \mathrm{IR}(\mathrm{KBr}) \nu_{\max }$ : 2918, 2848, 2362, 1699,1626, 1604, 1562, $1495 \mathrm{~cm}^{-1} ;{ }^{1} \mathrm{H}$ NMR $\left(400 \mathrm{MHz}, \mathrm{CDCl}_{3}\right): \delta 8.40(\mathrm{~d}, J=7.8 \mathrm{~Hz}, 1 \mathrm{H}), 7.82(\mathrm{t}$, $J=7.8 \mathrm{~Hz}, 1 \mathrm{H}), 7.76(\mathrm{~d}, J=7.8 \mathrm{~Hz}, 1 \mathrm{H}), 7.57-7.52(\mathrm{~m}, 2 \mathrm{H})$, $5.89(\mathrm{~d}, J=8.4 \mathrm{~Hz}, 1 \mathrm{H}), 5.10(\mathrm{br} \mathrm{s}, 2 \mathrm{H}), 1.91(\mathrm{~s}, 3 \mathrm{H}), 1.88(\mathrm{br}$ $\mathrm{s}, 2 \mathrm{H}), 1.53-1.45(\mathrm{br} \mathrm{s} 2 \mathrm{H}), 1.20(\mathrm{t}, J=6.3 \mathrm{~Hz}, 2 \mathrm{H}), 0.83(\mathrm{~s}$, $6 \mathrm{H}) ;{ }^{13} \mathrm{C}\left\{{ }^{1} \mathrm{H}\right\}$ NMR $\left(100 \mathrm{MHz}, \mathrm{CDCl}_{3}\right): \delta 172.7,146.5$, 140.9 , 136.2, 135.4, 134.1, 133.8, 133.2, 131.5, 125.1, 120.9, 120.3, 113.6, 90.4, 50.1, 46.2, 34.8, 28.9, 28.0 (2C), 22.7, 19.5; HRMS (ESI/QTOF) $m / z:[\mathrm{M}+\mathrm{H}]^{+}$calcd for $\mathrm{C}_{22} \mathrm{H}_{24}{ }^{35} \mathrm{ClN}_{2} \mathrm{O}$, 367.1572; found, 367.1568.

General Procedure of $\mathrm{N}$-Methylbenzene-1,2-diamine (4) or $\mathrm{N}$-(3-Methylbut-2-en-1-yl)benzene-1,2-diamine (6) with 4-Halo-1,2,3-benzenetriols (General Procedure B; Entries 2, 3, and 5 in Table 2). A solution of $N$ alkylbenzene-1,2-diamine (30.0 mg) and 4-halo-1,2,3-benzenetriols (1.0 equiv) in the presence of $\mathrm{Cs}_{2} \mathrm{CO}_{3}$ (1.0 equiv) in 2propanol was stirred under an $\mathrm{O}_{2}$ atmosphere at $\mathrm{rt}$ in the dark until no further TLC changes were observed. The reaction was quenched by the addition of $1 \mathrm{M}$ aqueous $\mathrm{HCl}$ solution. The mixture was diluted with $\mathrm{CHCl}_{3}$. After the layers were separated, the aqueous layer was neutralized with $4 \mathrm{M}$ aqueous $\mathrm{NaOH}$ solution. The aqueous layer was extracted with $\mathrm{CHCl}_{3}$ twice. The combined organic layer was dried over $\mathrm{Na}_{2} \mathrm{SO}_{4}$ and concentrated to give a residue. The residue was purified by silica gel column chromatography or reversed-phase flash chromatography.

2-Bromo-5-methylphenazin-1(5H)-one (1b). Following the general procedure $B$, the reaction was performed using $4(30.0$ $\mathrm{mg}, 245.6 \mu \mathrm{mol})$ and $10(50.7 \mathrm{mg}, 247.3 \mu \mathrm{mol})$ in the presence of $\mathrm{Cs}_{2} \mathrm{CO}_{3}(80.5 \mathrm{mg}, 247.1 \mu \mathrm{mol})$ in 2-propanol $(2.0$ $\mathrm{mL}$ ) under an $\mathrm{O}_{2}$ atmosphere for 3 days. The residue was purified by reversed-phase flash chromatography $(\mathrm{MeOH} /$ $\left.\mathrm{H}_{2} \mathrm{O}=2 / 1\right)$ to give $\mathbf{1 b}(12.7 \mathrm{mg}, 18 \%)$ as a dark-blue solid.

Marinocyanin $B(3 \boldsymbol{b})$. Following the general procedure $B$, the reaction was performed using $6(30.0 \mathrm{mg}, 170.2 \mu \mathrm{mol})$ and $10(35.8 \mathrm{mg}, 174.6 \mu \mathrm{mol})$ in the presence of $\mathrm{Cs}_{2} \mathrm{CO}_{3}(53.5$ $\mathrm{mg}, 164.2 \mu \mathrm{mol})$ in 2-propanol $(1.0 \mathrm{~mL})$ under an $\mathrm{O}_{2}$ atmosphere for 2 days. The residue was purified by silica gel column chromatography $\left(\mathrm{CHCl}_{3} / \mathrm{MeOH}=50 / 1\right)$ and reversed-phase flash chromatography $\left(\mathrm{MeOH} / \mathrm{H}_{2} \mathrm{O}=4 / 1\right)$ to give $3 \mathbf{b}(8.5 \mathrm{mg}, 15 \%)$ as a dark-blue solid. The structure of
$3 \mathbf{b}$ was confirmed by comparison of the ${ }^{1} \mathrm{H}$ and ${ }^{13} \mathrm{C}\left\{{ }^{1} \mathrm{H}\right\}$ NMR spectra with those reported for $3 \mathbf{b}^{22}$

2-Chloro-5-(3-methylbut-2-en-1-yl)phenazin-1(5H)-one (3c). Following the general procedure $\mathrm{B}$, the reaction was performed using $6(30.0 \mathrm{mg}, 170.2 \mu \mathrm{mol})$ and $9(27.3 \mathrm{mg}$, $170.0 \mu \mathrm{mol})$ in the presence of $\mathrm{Cs}_{2} \mathrm{CO}_{3}(55.6 \mathrm{mg}, 170.6 \mu \mathrm{mol})$ in 2-propanol $(1.5 \mathrm{~mL})$ under an $\mathrm{O}_{2}$ atmosphere for 2 days. The residue was purified by reversed-phase flash chromatography $\left(\mathrm{MeOH} / \mathrm{H}_{2} \mathrm{O}=2 / 1\right)$ to give $3 \mathrm{c}(10.6 \mathrm{mg}, 21 \%)$ as a dark-blue solid. Reversed-phase TLC $\left(\mathrm{MeOH} / \mathrm{H}_{2} \mathrm{O}=4 / 1\right) \mathrm{Rf}$ 0.38; mp 145-149 ${ }^{\circ} \mathrm{C}$; IR (KBr) $\nu_{\max }: 3035,2958,2918,2848$, $1724,1624,1562,1496 \mathrm{~cm}^{-1} ;{ }^{1} \mathrm{H}$ NMR (400 MHz, $\left.\mathrm{CD}_{3} \mathrm{OD}\right)$ : $\delta 8.31(\mathrm{~d}, J=7.8 \mathrm{~Hz}, 1 \mathrm{H}), 8.07-8.03(\mathrm{brm}, 1 \mathrm{H}), 7.99-7.93$ $(\mathrm{m}, 2 \mathrm{H}), 7.72(\mathrm{t}, J=7.8 \mathrm{~Hz}, 1 \mathrm{H}), 6.41(\mathrm{~d}, J=8.7 \mathrm{~Hz}, 1 \mathrm{H})$, 5.37 (br s, 2H), 5.21-5.18 (br s, $1 \mathrm{H}), 2.03$ (s, 3H), 1.80 (d, J $=0.9 \mathrm{~Hz}, 3 \mathrm{H}) ;{ }^{13} \mathrm{C}\left\{{ }^{1} \mathrm{H}\right\} \mathrm{NMR}\left(100 \mathrm{MHz}, \mathrm{CD}_{3} \mathrm{OD}\right): \delta 171.4$, $146.4,144.3,140.4,138.9,138.1,134.5,134.0,133.5,128.0$, $119.5,117.3,116.8,93.8,48.7^{*}, 25.6,18.7$ (*this carbon signal was assigned based on the HMQC spectrum.); HRMS (ESI/ QTOF) $m / z$ : $[\mathrm{M}+\mathrm{H}]^{+}$calcd for $\mathrm{C}_{17} \mathrm{H}_{16}{ }^{35} \mathrm{ClN}_{2} \mathrm{O}, 299.0946$; found, 299.0942 .

Cell Lines and Culturing. A549 cells were cultured at 37 ${ }^{\circ} \mathrm{C}$ with $5 \% \mathrm{CO}_{2}$ in Dulbecco's modified Eagle's medium (DMEM) supplemented with $10 \%$ fetal bovine serum (FBS). HL-60 cells were cultured at $37{ }^{\circ} \mathrm{C}$ with $5 \% \mathrm{CO}_{2}$ in Roswell Park Memorial Institute (RPMI) 1640 medium supplemented with 10\% FBS. MRC-5 cells were cultured in Minimum Essential Medium Eagle-alpha modification ( $\alpha$-MEM) without ribonucleosides and deoxyribonucleosides supplemented with $10 \%$ FBS.

Cytotoxicity Evaluation. Cell growth was evaluated using cell counting kit- 8 according to the manufacturer's instructions based on the WST-8 [2-(2-methoxy-4-nitrophenyl)-3-(4-nitrophenyl)-5-(2,4-disulfophenyl)-2H-tetrazolium, monosodium salt] assay. ${ }^{27}$ For the assay, the adherent A549 and MRC-5 cells were cultured in a 96-well plate with each well containing 2000 cells in a total volume of $100 \mu \mathrm{L}$, and HL-60 cells were cultured in a 96-well plate with each well containing 5000 cells in a total volume of $100 \mu \mathrm{L}$. The concentration of DMSO in the cell cultures was $0.1-0.2 \%(\mathrm{v} / \mathrm{v})$. The plates also included blank wells ( 0 cells) and control wells $(2000$ cells $/ 100 \mu \mathrm{L}$ for the adherent cells and 5000 cells $/ 100 \mu \mathrm{L}$ for HL-60 cells). A549 and MRC-5 cells were preincubated for $24 \mathrm{~h}$ before exposure to the test compounds. The plates were incubated with various concentrations of each compound for $72 \mathrm{~h}$. At the end of incubation, $10 \mu \mathrm{L}$ of the solution provided with the cell counting kit was then added, and the resulting mixture was incubated for $2 \mathrm{~h}$ at $37^{\circ} \mathrm{C}$. The absorbance values were then measured at $450 \mathrm{~nm}$ with a 96 -well plate reader. Cell growth inhibition was evaluated as the ratio of the absorbance of the sample to that of the control.

\section{ASSOCIATED CONTENT}

\section{Supporting Information}

The Supporting Information is available free of charge at https://pubs.acs.org/doi/10.1021/acsomega.0c04253.

${ }^{1} \mathrm{H},{ }^{13} \mathrm{C}\left\{{ }^{1} \mathrm{H}\right\}$, and 2D NMR spectra for synthetic compounds (PDF) 


\section{AUTHOR INFORMATION}

\section{Corresponding Author}

Kouji Kuramochi - Department of Applied Biological Science, Faculty of Science and Technology, Tokyo University of Science, Noda, Chiba 278-8510, Japan; 이이.org/0000-00030571-9703; Email: kuramoch@rs.tus.ac.jp

\section{Authors}

Haruki Kohatsu - Department of Applied Biological Science, Faculty of Science and Technology, Tokyo University of Science, Noda, Chiba 278-8510, Japan

Shogo Kamo - Department of Applied Biological Science, Faculty of Science and Technology, Tokyo University of Science, Noda, Chiba 278-8510, Japan; 이이.org/0000-00025799-4937

Masateru Furuta - Department of Applied Biological Science, Faculty of Science and Technology, Tokyo University of Science, Noda, Chiba 278-8510, Japan

Shusuke Tomoshige - Department of Applied Biological Science, Faculty of Science and Technology, Tokyo University of Science, Noda, Chiba 278-8510, Japan; (1) orcid.org/00000002-4948-5809

Complete contact information is available at:

https://pubs.acs.org/10.1021/acsomega.0c04253

\section{Notes}

The authors declare no competing financial interest.

\section{ACKNOWLEDGMENTS}

This study was partly supported by JSPS KAKENHI (no. 20K05868) to K.K.

\section{REFERENCES}

(1) Cimmino, A.; Culver, C. A.; van Breemen, R. B. Phenazines and Cancer. Nat. Prod. Rep. 2012, 29, 487-501.

(2) Pierson, L. S., III Metabolism and Function of Phenazines in Bacteria: Impacts on the Behavior of Bacteria in the Environment and Biotechnological Process. Appl. Microbiol. Biotechnol. 2010, 86, 16591670.

(3) Laursen, J. B.; Nielsen, J. Phenazine Natural Products: Biosynthesis, Synthetic Analogues, and Biological Activity. Chem. Rev. 2004, 104, 1663-1686.

(4) Guttenberger, N.; Blankenfeldt, W.; Breinbauer, R. Recent Developments in the Isolation, Biological Function, Biosynthesis, and Synthesis of Phenazine Natural Products. Bioorg. Med. Chem. 2017, $25,6149-6166$.

(5) Jayaseelan, S.; Ramaswamy, D.; Dharmaraj, S. Pyocyanin: Production, Applications, Challenges and New Insights. World J. Microbiol. Biotechnol. 2014, 30, 1159-1168.

(6) Lau, G. W.; Hassett, D. J.; Ran, H.; Kong, F. The Role of Pyocyanin in Pseudomonas aeruginosa Infection. Trends Mol. Med. 2004, 10, 599-606.

(7) Price-Whelan, A.; Dietrich, L. E. P.; Newman, D. K. Rethinking 'Secondary' Metabolism: Physiological Roles for Phenazine Antibiotics. Nat. Chem. Biol. 2006, 2, 71-78.

(8) Meirelles, L. A.; Newman, D. K. Both Toxic and Beneficial Effects of Pyocyanin Contribute to the Lifecycle of Pseudomonas aeruginosa. Mol. Microbiol. 2018, 110, 995-1010.

(9) Glasser, N. R.; Saunders, S. H.; Newman, D. K. The Colorful World of Extracellular Electron Shuttles. Annu. Rev. Microbiol. 2017, $71,731-751$.

(10) Costa, K. C.; Glasser, N. R.; Conway, S. J.; Newman, D. K. Pyocyanin Degradation by a Tautomerizing Demethylase Inhibits Pseudomonas aeruginosa Biofilms. Science 2017, 355, 170-173.
(11) Imai, S.; Furihata, K.; Hayakawa, Y.; Noguchi, T.; Seto, H. Lavanducyanin, a New Antitumor Substance Produced by Streptomyces sp. J. Antibiot. 1989, 42, 1196-1198.

(12) Nakayama, O.; Yagi, M.; Tanaka, M.; Kiyoto, S.; Okuhara, M.; Kohsaka, M. WS-9659 A and B, Novel Testosterone $5 \alpha$-Reductase Inhibitors Isolated from a Streptomyces. I. Taxonomy, Fermentation, Isolation, Physico-chemical Characteristics. J. Antibiot. 1989, 42, $1221-1229$.

(13) Nakayama, O.; Shigematsu, N.; Katayama, A.; Takase, S.; Kiyoto, S.; Hashimoto, M.; Kohsaka, M. WS-9659 A and B, Novel Testosterone $5 \alpha$-Reductase Inhibitors Isolated from a Streptomyces. II. Structural Elucidation of WS-9659 A and B. J. Antibiot. 1989, 42, $1230-1234$.

(14) Nakayama, O.; Arakawa, H.; Yagi, M.; Tanaka, M.; Kiyoto, S.; Okuhara, M.; Kohsaka, M. WS-9659 A and B, Novel Testosterone $5 \alpha$ Reductase Inhibitors Isolated from a Streptomyces. III. Biological Characteristics and Pharmacological Characteristics. J. Antibiot. 1989, $42,1235-1240$.

(15) Kondratyuk, T. P.; Park, E.-J.; Yu, R.; van Breemen, R. B.; Asolkar, R. N.; Murphy, B. T.; Fenical, W.; Pezzuto, J. M. Novel Marine Phenazines as Potential Cancer Chemopreventive and Antiinflammatory Agents. Mar. Drugs 2012, 10, 451-464.

(16) Omura, S.; Eda, S.; Funayama, S.; Komiyama, K.; Takahashi, Y.; Woodruff, H. B. Studies on a Novel Antitumor Antibiotic, Phenazinomycin: Taxonomy, Fermentation, Isolation, and Physicochemical and Biological Characteristics. J. Antibiot. 1989, 42, 10371042.

(17) Funayama, S.; Eda, S.; Komiyama, K.; Ōmura, S.; Tokunaga, T. Structure of Phenazinomycin, a Novel Antitumor Antibiotic. Tetrahedron Lett. 1989, 30, 3151-3154.

(18) Li, S.; Hu, X.; Li, L.; Hu, X.; Wang, J.; Hu, X.; Liu, H.; Yu, L.; You, X.; Jiang, B.; Wu, L. 1-Hydroxy-7-oxolavanducyanin and $\Delta 7^{\prime \prime}, 8^{\prime \prime}$ 6"-Hydroxynaphthomevalin from Streptomyces sp. CPCC 203577. J. Antibiot. 2020, 73, 324-328.

(19) Asolkar, R. N.; Singh, A.; Jensen, P. R.; Aalbersberg, W.; Carté, B. K.; Feussner, K.-D.; Subramani, R.; DiPasquale, A.; Rheingold, A. L.; Fenical, W. Marinocyanins, Cytotoxic Bromo-phenazinone Meroterpenoids from a Marine Bacterium from the Streptomycete Clade MAR4. Tetrahedron 2017, 73, 2234-2241.

(20) Selected reports on the synthesis of pyocyanin: (a) Surrey, A R. Pyocyanine. Org. Synth. 1946, 26, 86-90. (b) Surrey, A. R. Pyocyanin. Org. Synth. Collect. 1955, 3, 753-756. (c) McIlwain, H. Phenazine series. VI. Reactions of Alkylphenazonium. Salts; the Phenazyls. J. Chem. Soc. 1937, 1704-1711. (d) Mortzfeld, F. B.; Pietruszka, J.; Baxendale, I. R. A Simple and Efficient Flow Preparation of Pyocyanin a Virulence Factor of Pseudomonas aeruginosa. Eur. J. Org. Chem. 2019, 2019, 5424-5433.

(21) A report on the synthesis of lavanducyanin: Kinoshita, Y.; Watanabe, H.; Kitahara, T.; Mori, K. Concise Construction of $N$ Alkylated Phenazinone Skeletons: Synthesis of Lavanducyanin (WS9659A). Synlett 1995, 186-188.

(22) Kohatsu, H.; Kamo, S.; Tomoshige, S.; Kuramochi, K. Total Syntheses of Pyocyanin, Lavanducyanin, and Marinocyanins A and B. Org. Lett. 2019, 21, 7311-7314.

(23) Bondi, A. van der Waals Volumes and Radii. J. Phys. Chem. 1964, 68, 441-451.

(24) Li, J.-T.; Wang, L.-X.; Wang, D.-X.; Zhao, L.; Wang, M.-X. Synthesis, Resolution, Structure, and Racemization of Inherently Chiral 1,3-Alternate Azacalix[4]pyrimidines: Quantification of Conformation Mobility. J. Org. Chem. 2014, 79, 2178-2188.

(25) Smith, T. J.; Wearne, R. H.; Wallis, A. F. A. Preparation of Chlorosyringols and Chloropyrogallols-components of Pulp Bleaching Effluents. Chemosphere 1994, 28, 921-930.

(26) Pla, D.; Albericio, F.; Álvarez, M. Regioselective Monobromination of Free and Protected Phenols. Eur. J. Org. Chem. 2007, 2007, $1921-1924$.

(27) Ishiyama, M.; Miyazono, Y.; Sasamoto, K.; Ohkura, Y.; Ueno, K. A Highly Water-soluble Disulfonated Tetrazolium Salt as a 
Chromogenic Indicator for NADH as well as Cell Viability. Talanta 1997, 44, 1299-1305.

(28) Badisa, R. B.; Darling-Reed, S. F.; Joseph, P.; Cooperwood, J. S.; Latinwo, L. M.; Goodman, C. B. Selective Cytotoxic Activities of Two Novel Synthetic Drugs on Human Breast Carcinoma MCF-7 Cells. Anticancer Res. 2009, 29, 2993-2996.

(29) Musa, M. A.; Badisa, V. L. D.; Latinwo, L. M.; Waryoba, C.; Ugochukwu, N. In Vitro Cytotoxicity of Benzopyranone Derivatives with Basic Side Chain Against Human Lung Cell Lines. Anticancer Res. 2010, 30, 4613-4617.

(30) Zainal-Abidin, M. H.; Hayyan, M.; Ngoh, G. C.; Wong, W. F. Doxorubicin Loading on Functional Graphene as a Promising Nanocarrier Using Ternary Deep Eutectic Solvent Systems. ACS Omega 2020, 5, 1656-1668.

(31) Kaneda, N.; Nagata, H.; Furuta, T.; Yokokura, T. Metabolism and Pharmacokinetics of the Camptothecin Analogue CPT-11 in the Mouse. Cancer Res. 1990, 50, 1715-1720.

(32) Liu, K.; Wang, X.; Sha, K.; Zhang, F.; Xiong, F.; Wang, X.; Chen, J.; Li, J.; Churilov, L. P.; Chen, S.; Wang, Y.; Huang, N. Nuclear Protein HMGN2 Attenuates Pyocyanin-induced Oxidative Stress via Nrf2 Signaling and Inhibits Pseudomonas aeruginosa Internalization in A549 Cells. Free Radic. Biol. Med. 2017, 108, 404-417.

(33) Garrison, A. T.; Abouelhassan, Y.; Kallifidas, D.; Bai, F.; Ukhanova, M.; Mai, V.; Jin, S.; Luesch, H.; Huigens, R. W., III Halogenated Phenazines that Potently Eradicate Biofilms, MRSA Persister Cells in Non-Biofilm Cultures and Mycobacterium tuberculosis. Angew. Chem., Int. Ed. 2015, 54, 14819-14823.

(34) Garrison, A. T.; Abouelhassan, Y.; Norwood, V. M.; Kallifidas, D.; Bai, F.; Nguyen, M. T.; Rolfe, M.; Burch, G. M.; Jin, S.; Luesch, H.; Huigens, R. W., III Structure-Activity Relationships of a Diverse Class of Halogenated Phenazines that Targets Persistent, AntibioticTolerant Bacterial Biofilms and Mycobacterium tuberculosis. J. Med. Chem. 2016, 59, 3808-3825.

(35) Xu, Z.; Yang, Z.; Liu, Y.; Lu, Y.; Chen, K.; Zhu, W. Halogen Bond: Its Role Beyond Drug-Target Binding Affinity for Drug Discovery and Development. J. Chem. Inf. Model. 2014, 54, 69-78. 